\title{
Familial progressive cardiac conduction defect
}

INSERM

\section{Source}

INSERM. (1999). Orphanet: an online rare disease and orphan drug data base. Familial progressive cardiac conduction defect. ORPHA:871

Familial progressive cardiac conduction defect (PCCD) is a hereditary cardiac conduction disorder that may progress to complete atrioventricular (AV) block. The disease is either asymptomatic or manifests as dyspnea, dizziness, syncope, abdominal pain, heart failure or sudden death. 